\title{
Practise what you preach: a faith-based approach to conservation in Indonesia
}

\author{
Jeanne E. McKay, Fachrudin M. Mangunjaya, Yoan Dinata, Stuart \\ R. HARROP and FAZLUN KHALID
}

\begin{abstract}
Faith-based teachings on the environment have been identified as a potentially effective form of conservation outreach but one that remains largely untested. Indonesia contains $10 \%$ of the world's tropical rainforests and is the most populous Muslim country. A faith-based approach to conservation could therefore yield significant conservation benefits here. Within Islam several key principles in the Qur'an underpin and outline the role of humans in nature conservation. Here, we report on a Darwin Initiative project component that sought to assess the applicability of Islamic teachings to conservation action in West Sumatra. We developed water-conservation-themed sermons that were delivered by project-trained religious leaders in 10 mosques and nine Islamic boarding schools during the holy month of Ramadan. We conducted entryexit questionnaire surveys to assess levels of concern, awareness and intent to act amongst male $(\mathrm{n}=389)$ and female $(n=479)$ worshippers. The results revealed that greater attention should be paid to raising awareness of the linkages between Islam and conservation rather than on conservation principles alone, which were already adequately understood. This study provides the first insights into the important role that women could play within a faith-based project. Female respondents demonstrated greater knowledge and understanding of Islamic teachings about the environment and the services provided by watershed forests. They were also more likely to contribute to conservation activities, suggesting that future projects should seek to involve this often marginalized stakeholder group fully, as well as provide practical ways for men and women to transform words into action.
\end{abstract}

Keywords Biodiversity, customary law, deforestation, ecosystem services, Indonesia, Islam, REDD, religion

\footnotetext{
JeAnNe E. MCKay (Corresponding author) and StUart R. Harrop Durrell Institute of Conservation and Ecology, University of Kent, Canterbury, Kent, CT2 7NR, UK. E-mail jeanne.e.mckay@gmail.com

FACHRUDDIN M. MANGUNJAYA ${ }^{*}$ Conservation International, Indonesia Programme, Jakarta, Indonesia

YoAn DinATA Fauna \& Flora International, Indonesia Programme, Jakarta, Indonesia

FAzLUN KHALID Islamic Foundation for Ecology and Environmental Sciences, Birmingham, UK

${ }^{*}$ Current address: Universitas Nasional Jakarta, Pejaten, Jakarta, Indonesia

Received 9 April 2013. Revision requested 11 June 2013.

Accepted 6 July 2013. First published online 8 November 2013.
}

\section{Introduction}

7 he vast Indonesian archipelago contains nearly a third $1(32 \%)$ of the rainforest of South and South-east Asia (FAO \& JRC, 2012). This plays a range of critical roles that include providing ecosystem services for rural communities, maintaining biodiversity and regulating climate change (Kremen et al., 2000). Unfortunately, Indonesia, and in particular the western island of Sumatra, has some of the highest annual rates of tropical deforestation in the tropics ( $>2 \%$ loss per year), especially beyond protected areas, which makes it the world's third largest carbon emitter (Measey, 2010).

In an attempt to curtail forest loss the Government of Indonesia has voluntarily taken on a leadership role in combating climate change by independently pledging to reduce its carbon emissions by $26 \%$ over the next 10 years through the design and implementation of a national REDD+ (Reducing Emissions from Deforestation and Forest Degradation) strategy (GoI, 2011). For this strategy to be effective Indonesia will need a wide range of management approaches that include not only the well-established, such as land-use planning and law enforcement, but also a renewed effort to secure strong community support.

Indonesia has the world's largest Muslim population ( $87 \%$ of its $240 \mathrm{~m}$ people) and Islamic teachings have a strong influence on daily life (BPS, 2010; Mangunjaya \& McKay, 2012). Within Islam there are several key principles relating to the human role in conserving natural resources: tauhid (integration), khalifah (guardian/steward), mizan (balance) and fitrah (nature). Furthermore, there are three largely underutilized Islamic land-use traditions (McKay, 2013) that apply to nature conservation: hima (management zones established for sustainable natural resource use), harim (inviolable sanctuaries used for protecting water resources and their services), and ihya al-mawat (reviving neglected land to become productive).

Applying a religious approach to raise environmental awareness amongst Muslims is not a new concept in Indonesia. The earliest attempt was made in 1999 by the Institute of Ecology in Bandung, and the Islamic Foundation for Ecology and Environmental Sciences and partners have been involved in a series of training exercises since 2002 that have developed environmental themes, based on the Qur'an, for Islamic scholars, teachers, activists and community leaders. In 2006 the Indonesian Council of Ulama issued the first of two fatwas (Islamic legal opinions) 
on illegal logging and mining activities in Kalimantan, proclaiming them to be haram (forbidden). The second fatwa (in 2011) took this one step further by working with the national government to provide a comprehensive set of legally binding guidelines to support the first fatwa (MUI, 2011). This prompted the President of Indonesia to dispatch 5,000 ulamas (religious leaders) across the archipelago to raise awareness and concern over climate change issues, with the aim of tackling illegal logging (The Jakarta Post, 2011).

The Government of Indonesia, along with civil society and local and international NGOs from 14 countries, hosted the first International Conference on Muslim Action on Climate Change in April 2010, which produced a set of climate change mitigation recommendations for conference members to endorse and administer in their own country. At the local level several 'green' initiatives on social forestry and replanting degraded lands have also been conducted through pesantrens (Islamic boarding schools; Mangunjaya \& McKay, 2012).

These actions demonstrate that the environmental cause is not just a secular one and that there is largely unexplored potential for integrating a religious approach into practical conservation efforts. A sizeable body of knowledge has recently been amassed linking faith and the environment (Dudley et al., 2009; Bhagwat et al., 2011; Mikusiński et al., 2013). However, little research has been conducted on the applicability of religious principles in a practical context and whether employing such an approach can change behaviour, or show an intent to do so, rather than just changing attitudes (which on its own does not guarantee improved conservation outcomes).

Here, we focus on one component of a 3-year Darwin Initiative project that sought to identify Islamic teachings relating to the environment and incorporate them into conservation action within two areas in the forest-rich Indonesian province of West Sumatra. More specifically, we assess the effectiveness of the project's Ramadan campaign in raising levels of knowledge, concern and intent to act towards protecting watershed forests, with a strong emphasis on safeguarding their ecosystem services.

\section{Study area}

The project focused on two rural communities and one urban community in West Sumatra: Guguk Malalo in Tanah Datar district, Pakan Rabaa Timur in Solok Selatan district, and Padang, the capital and largest city of West Sumatra. At $500 \mathrm{~m}$ altitude, Guguk Malalo spans 5,280 ha along the western coast of Lake Singkarak, one of the major lakes in West Sumatra. Based on 2006 census data, 4,384 people (2,144 males and 2,240 females) live in the area (BPS, 2010). The majority of the adult male inhabitants are farmers and fishermen. The women mostly care for their children and in their free time gather firewood and work on their farmland. The forest area, which comprises both a nature reserve and protected forest, is threatened by illegal activities such as logging and wildlife poaching, according to interviews conducted by local project staff with community members.

Pakan Rabaa Timur is 21,500 ha of predominantly forested area, with $c$. one third used for farming. Its fertile soil is predominantly used for growing cocoa, rubber and soybean. The population is 3,565 people (1,691 males, 1,874 females; BPS, 2010). The majority of its male inhabitants are farmers and the women mostly care for their children and work on their farmland. Although the majority of the forest forms part of a protected area, community members here also claim that the forest faces a considerable threat of deforestation because of illegal logging and mining by local inhabitants and people from neighbouring communities.

Both rural sites were selected based on criteria developed by local and UK-based project partners (West SumatraNatural Resources and Conservation Office, Conservation International-Indonesia programme, Fauna \& Flora International-Indonesia programme, the Islamic State Institute, the Minangkabau Customary Organization, the Indonesian Board of Religious Leaders, the University of Andalas, the Durrell Institute of Conservation and Ecology, and the Islamic Foundation for Ecology and Environmental Sciences). These partners placed a priority on the existence of a strong customary law regime, an interest in participating in the project and reasonable accessibility from Padang. Religious beliefs were not included as a criterion because as elsewhere in Indonesia, Islam is the prevailing religion in West Sumatra (88\% of the population; Miller, 2009).

A preliminary survey conducted by project staff and partners in Guguk Malalo and Pakan Rabaa Timur identified that the Islamic land-management systems of hima, harim and ihya al-mawat were loosely practised within the communities through their legally recognized adat (customary) systems. However, both a lack of awareness amongst community members that these systems were Islamic and lack of institutional capacity to implement them (training and start-up funds being the main restrictions) hindered their effectiveness in the sustainable management of forests and their ecosystem services.

\section{Methods}

\section{Data collection}

In preparation for the Islamic holy month of Ramadan in August 2011, an environmental-themed Ramadan campaign comprising a sermon and accompanying guidelines was jointly developed by two project partner ulamas, with 
support from Darwin Initiative project staff. These sermons were administered before the evening taraweh prayers, a non-obligatory session of prayers during Ramadan attended by both men and women, which provided a rare opportunity to address both sexes. The project focused on eight urban mosques (in Padang) and the single mosque at each of the rural sites where the ulamas themselves preached. Also as part of the campaign, project staff developed and delivered a Ramadan conservation curriculum (a set of environmental-themed Islamic teaching materials and accompanying lectures) for nine pesantrens in Padang. Both the sermon and curriculum focused on the importance of watershed forests in providing a key ecosystem service of clean and regular water supplies, which provide daily benefits to rural communities (as they live at the foot of the watershed forests) and urban populations in Padang and neighbouring districts (whose water supply is sourced from the surrounding hill forests and whose energy is partially supplied by hydro-power from Lake Singkarak in Guguk Malalo).

The sermon included several water-related sections, including scientific facts related to water, its importance and how to conserve water locally. These messages were further strengthened with passages from the Qur'an that dealt specifically with water and its importance to mankind, as well as quotations from Sunan Ibn Majah, one of six major hadith (sayings or acts that have been ascribed to the Prophet of Islam, collected by Ibn Majah). Next, the project developed two similar questionnaire surveys to measure the effect of the mosque sermon and pesantren curriculum. The questionnaire was designed after that developed by Clements et al. (2009) to ascertain whether Islamic sermons were an effective means to raise awareness of turtle conservation in Malaysia. Our questionnaires consisted of three main sections, designed to ascertain level of concern, knowledge gained from the sermons and intent to act upon the conservation messages received. However, unlike Clements et al. (2009), we also sought an explicit link with the environmental teachings of the Qur'an, a greater number of respondents and the inclusion of women.

Demographic and socio-economic information, including gender, age, origin, occupation and highest level of formal education were collected for all respondents. One question was used to ascertain a respondent's level of concern: (1) how much of a hypothetical IDR 5 million (c. USD 500) would he or she allocate for community infrastructure, disaster relief, forest watershed conservation projects and other uses (which they were asked to name). A second question was used to determine intent to act: (2) would he or she participate in water conservation activities (daily, weekly, monthly or annually) or not. Three questions were then used to determine whether knowledge was gained from the sermon text: (3) what are the three important benefits provided by watershed forests to people; (4) what three things did the Messenger of Allah say Muslims were associated with; and (5) select three key threats to water quality in West Sumatra. The questionnaire survey was intentionally short so that a sufficiently large sample size (with a target of $>40$ respondents per mosque) could be obtained whilst being respectful of prayer rituals.

The mosque surveys were conducted in August and September 2011. The questionnaires were administered by 15 project staff and trained volunteers to randomly selected worshippers entering and exiting the mosques. When one respondent had finished answering the questions, the interviewers then selected the next nearest person entering or exiting the mosque, to remove a selection bias. Where possible, the interviewers aimed to collect data from a similar number of men and women. A single questionnaire survey took 5-7 minutes to complete. For the pesantren survey the questionnaire was adapted slightly to reflect the curriculum content, which also included information on climate change issues. Four project staff administered the same questionnaire to the same students before and after the programme.

\section{Data analysis}

All questionnaire responses were compiled and analysed in SPSS v. 14.0 (SPSS, Chicago, USA). Using the same analytical method as Clements et al. (2009), to enable direct comparison, a binomial test was performed to measure changes in the proportion of respondents prioritizing watershed forest conservation before and after the mosque sermons or the pesantren curriculum, which were analysed separately. Descriptive statistics were used to determine the percentage changes in levels of knowledge, concern and intent to act in relation to environmental issues in the exit and entry survey groups. Next, either a Mann-Whitney U, $\chi^{2}$ or Spearman's Rank Correlation Coefficient test was performed to investigate which demographic or socioeconomic factors explained a positive response in the entry group only, and a general linear model was used to compare the entry and exit groups and the factors associated with changes.

\section{Results}

\section{Mosque survey}

From the respondents interviewed before $(n=253)$ and after $(n=259)$ the sermon at 10 mosques, the results revealed that the teachings had raised levels of concern: the proportion of people who prioritized funding for watershed 
forest conservation in the exit group $(\mathrm{P}=0.22)$ was significantly higher than that of the entry group $(\mathrm{P}=0.14$; binomial test: $\mathrm{P}<0.01$ ), but nevertheless still low. The mean amount of money that respondents were prepared to allocate did not significantly increase after the sermon $(\mathrm{P}=0.123, Z=-1.543)$. Levels of concern, based on an intent to participate in a conservation activity, were already high among people entering the mosques ( $96.4 \%$ would participate before and $95.4 \%$ after) and there were no significant differences between entry and exit answers, even after controlling for socio-economic variables (age, educational level and gender).

Of the entry group, younger $\left(\mathrm{P}<0.001, r_{\mathrm{s}}=-0.190\right)$ and better educated $\left(\mathrm{P}<0.01, \chi^{2}=17.439\right)$ respondents were more likely to identify correctly the ecosystem services provided by watershed forests, compared to other respondents. Younger $\left(\mathrm{P}=0.044, r_{\mathrm{s}}=-0.89\right)$ and better educated $\left(\mathrm{P}<0.001, \chi^{2}=18.838\right)$ respondents also tended to identify correctly the threats to water quality in West Sumatra. However, on religious issues, female $(\mathrm{P}=0.027, Z=-2.213)$ and less educated $\left(\mathrm{P}=0.003, \chi^{2}=11.565\right)$ respondents tended to identify more correct answers on Islamic teaching towards the environment.

Levels of knowledge were generally low before the sermon and the subsequent increase was not significant (47.3\% knew of the benefits of watershed forests before and $52.9 \%$ after; $31.2 \%$ knew the message before and $39.8 \%$ after). Knowledge of the threats to watershed forests was already high ( $79.8 \%$ correctly identified the threats, which increased to $84.2 \%$ after the sermon, $\mathrm{P}>0.05$ ), and there were no significant differences in entry-exit answers, even after controlling for socio-economic variables (age, educational level and gender).

\section{Pesantren survey}

The results of the interviews before $(n=198)$ and after $(\mathrm{n}=158)$ the Ramadan campaign curriculum in nine pesantrens revealed that the teachings raised the students' level of concern. The proportion of people who prioritized funding for watershed forest conservation in the exit group $(\mathrm{P}=0.24)$ was significantly higher than that in the entry group $(\mathrm{P}=0.06$; binomial test: $\mathrm{P}<0.01)$ but nevertheless was still low. Levels of concern, based on intent to participate in a conservation activity, were already high among those entering the pesantren ( $95.5 \%$ would participate before and $94.9 \%$ after) and there were no significant differences in entry-exit answers, even after controlling for socioeconomic variables (age, educational level and gender). Of the entry group, female $(\mathrm{P}<0.005, \mathrm{Z}=-2.839)$ respondents were more likely to identify correctly the services provided by watershed forests and to contribute their time to conservation activities $(\mathrm{P}=0.011, \mathrm{Z}=-2.555)$.
Levels of knowledge of the focal areas varied before the respondents were engaged through the curriculum. The number of respondents who knew of the benefits provided by watershed forests significantly increased (from $44.9 \%$ to $62.0 \%$ ) in the exit group, even after controlling for socioeconomic variables (pesantren and gender: $F_{1,35}=2.712$, $\left.\mathrm{P}<0.05, r^{2}=0.229\right)$. Some respondents correctly identified the effects of global warming before and after $(41.4 \%$ and $52.5 \%$, respectively), but there was no significant change in entry-exit answers, even after controlling for socioeconomic variables. Levels of knowledge were higher for two questions $(87.4 \%$ knew the causes of global warming before and $88.0 \%$ after, and $81.8 \%$ knew of their duty as Muslims to guard Allah's creation before and $84.8 \%$ after) but there was no significant change in entry-exit answers, even after controlling for socio-economic variables (mosque and gender).

\section{Discussion}

Results from the survey indicated that the sermons and pesantren curriculum raised levels of concern amongst all respondents, although in some instances they remained low (as measured through the funding prioritization response). Female respondents scored higher than males, in addition to being more likely to contribute their time to conservation activities. This raises an important issue when considering the prominent positions that men hold within Islam and the importance of engaging women in a project of this nature. Our results revealed that female respondents tended to identify more correct answers on Islamic teachings towards the environment (in the mosque survey) and the services provided by watershed forests (in the pesantren survey). This result indicates that there is an opportunity to support the active involvement of women in conservation activities, especially in West Sumatra.

The Minangkabau ethnic group of West Sumatra is the largest matrilineal society in the world (Yonariza, 1998). Although religious and political affairs remain largely under the influence of male family and community members, and contrary to the fact that women are less likely to own land (Schneider, 2013), it is the Minangkabau women who inherit and are responsible for maintaining all property (including traditional lands). That these women may also be more likely to contribute their time to conservation activities concurs with their active contribution in project meetings and activities, as shown by other studies on the role of women in forest management (Agarwal, 2009; Sodhi et al., 2010). Thus, within this Darwin Initiative project women should have been more actively targeted to achieve greater conservation outcomes. 
Although the Darwin Initiative project had a strong focus on Muslim men as the primary sources of religious stewardship, the women also played an important part, albeit often indirectly, in the project's overall success. For example, a local project partner from Pakan Rabaa Timur was the first person in her community to plant cocoa trees on her land. After a process of trial and error and despite receiving virtually no support from her community, and having to overcome their initial scepticism, she currently has several hectares of thriving, fruiting trees from which she receives IDR 1.5 million per month, which is a $50 \%$ increase in her household income. She has also provided samples and advice to 10 of her neighbours, who have planted cocoa on their land, wishing to replicate her success, and a further 50 community members are currently planting cocoa seedlings from the now locally managed Darwin Initiative project tree nursery. Given this widespread replication, future projects in West Sumatra could specifically seek to include women's groups and the matrilineal heads of families (who are responsible for familial lands) both in conservation activities and project steering committees. This would also provide useful information regarding the nature of matrilineal societies and to what extent women are empowered to make decisions regarding their lands, both in a wider context and specifically in West Sumatra.

The results of our study show that levels of knowledge regarding the importance of watersheds and the threats to them, as well as the intent to participate in a conservation activity, were already high prior to attending the sermon. This is similar to the results of Clements et al. (2009); both projects were active prior to conducting surveys and this may have led to benign responses. However, our study suggests that rather than directing efforts towards raising general awareness on conservation issues, greater results could be achieved through raising awareness of the environmental teachings of Islam (as well as providing the practical means with which to implement them).

An unexpected outcome of the project was the noted pause for reflection from many religious leaders and followers, both men and women, when introduced for the first time to the environmental teachings and resource management systems outlined in the Qur'an. Therefore, taking this awareness further and supporting practical ways in which these teachings can be implemented at both local and national levels and by both men and women is an important consideration, especially when focusing on sustainable resource use and ecosystem service protection.

In Indonesia the Islamic Foundation for Ecology and Environmental Sciences has been involved in several programmes that have sought to raise awareness regarding Islamic teachings on the environment. Supported by the World Bank and the Alliance of Religion and Conservation, the Foundation conducted two workshops in 2002 focused on raising awareness amongst communities living in the buffer zone around Kerinci Seblat National Park in westcentral Sumatra (World Bank, 2006) and a second workshop at Luhur al Wasilah pesantren in Garut, West Java. A colloquium on Islamic figh (jurisprudence) on the environment was also organized the same year (supported by the UK-based charity Muslim Hands, Conservation International, the State Islamic University and Indonesia's Ministry of Environment), bringing together leading Indonesian scholars and their international counterparts to explore the basis of Islamic law on the environment. In 2006, with further support from Muslim Hands, the workshops were repeated amongst communities living around Batang Gadis National Park, North Sumatra (Lubis, 2006) and again with Islamic scholars in post-tsunami Aceh. Further initiatives also included the translation of a training resource, 'Qur'an, Creation and Conservation', into Indonesian (Al Qur'an Ciptaan dan Konservasi) in 2007.

In addition to the examples in Indonesia (Java, Sumatra and Kalimantan), there has been demonstrable success in employing such a strategy elsewhere. The Islamic Foundation for Ecology and Environmental Sciences and CARE International have worked with local fishing communities and Islamic leaders since 1999 to establish an ethics-based conservation programme (derived from the Qur'an and land management teachings in the Shariah), for sustainably managing coral reefs in Zanzibar (Chernela et al., 2002; Gambrill, 2011). Not only did this project eradicate destructive dynamite fishing practices near the coral, it conducted a participatory planning exercise in which sustainable fishing and conservation zones were demarcated and have since been followed (IFEES, 2006).

Indonesia is the most populous Muslim country and there is a growing interest in supporting conservation activities and cooperating with local environmental groups and NGOs there, particularly amongst religious leaders and within the pesantrens (of which there are 21,521; Kementarian Agama Republik Indonesia, 2009). This level of cooperation may partly be a result of the existing awareness of the responsibility placed on all Muslims to act as guardians (khalifah) over God's creation (Mangunjaya \& Abbas, 2009). Furthermore, many will have witnessed the negative effects of damage to the environment, such as flooding, mudslides and changes in microclimates, within their own communities. Seeking ways to encourage religious leaders and local communities to act upon faith-based teachings on the environment must continue if conservation benefits are to be realized. For example, involving community members directly in the planning and implementation phases of our Darwin Initiative project created a strong sense of ownership and pride in the now independently run Darwin Initiative project tree nurseries. It also generated a strong commitment from each community to continue conducting annual green mosque 
campaigns, community litter clean-ups and replanting activities around water sources (using species from the nurseries).

Whether the 5,000 ulamas dispatched by the President of Indonesia can deliver tangible benefits to forest conservation remains to be seen. However, for their message to be capitalized upon from a conservation perspective it should also form part of a wider programme that enables both men and women to become actively involved in conservation activities through the teachings of the Qur'an. If put into practice this could provide both a useful and culturally appropriate complement to mainstay approaches to conservation (such as protected area management and law enforcement) in Indonesia and provide a model for elsewhere in the Muslim world.

\section{Acknowledgements}

We thank our local project staff members, Yolamalinda and Indra Saakti for collecting the pre- and post-questionnaire surveys and collating the data. We express our appreciation to local project partners the British Council, BKSDA, Fauna \& Flora International (particularly Darmawan Liswanto and Yasser Premana), Qbar and the University of Andalas for their participation and support in outreach and training activities. Special thanks to Matthew Linkie for providing helpful comments. Finally, our deepest gratitude to the Minangkabau community members, customary and religious leaders in our two West Sumatran study sites, Guguk Malalo and Pakan Rabbaa Timur. The project was funded by the UK's Department of Environment, Food and Rural Affairs through a Darwin Initiative grant.

\section{References}

Agarwal, B. (2009) Gender and forest conservation: the impact of women's participation in community forest governance. Ecological Economics, 68, 2785-2799.

Bhagwat, A.S., Dudley, N. \& Harrop, S.R. (2011) Religious following in biodiversity hotspots: challenges and opportunities for conservation and development. Conservation Letters, 4, 234-240.

BPS (Badan Pusat Statistik) (2010) The 2010 Indonesia Population Census. Government of Indonesia, Jakarta, Indonesia.

Chernela, J.M., Ahmad, A., Khalid, F., Sinnamon, V. \& JAIRETh, H. (2002) Innovative governance of fisheries and ecotourism in community-based protected areas. Parks, 12, 28-41.

Clements, R., Foo, R., Othman, S., Rahman, U., Mustafa, S.R.S. \& ZulKifli, R. (2009) Islam, turtle conservation and coastal communities. Conservation Biology, 23, 516-517.

Dudley, N., Higgins-Zogib, L. \& Mansourian, S. (2009) The links between protected areas, faiths, and sacred natural sites. Conservation Biology, 23, 568-577.

FAO \& JRC (Food and Agriculture Organization of the United Nations \& European Commission Joint Research
Centre) (2012) Global Forest Land-Use Change 1990-2005. FAO Forestry Paper No. 169. FAO, Rome, Italy.

Gambrill, A. (2011) From practice to policy to practice: connecting faith and conservation in Africa. International Resources Group for USAID Bureau for Africa, Washington, DC, USA.

GoI (Government of Indonesia) (2011) Strategi Nasional REDD+. National Development Planning Agency, Jakarta, Indonesia. Http:// ukp.go.id/informasi-publik/doc_details/12-draft-final-strateginasional-redd [accessed December 2012].

ifEES (Islamic Foundation for Ecology and Environmental SCIENCES) (2006) Inspiring change in Zanzibar. Eco-Islam, 1, 4-5.

Kementerian Agama Republik Indonesia (2009) Deskriptif Statistik Pondok Pesantren dan Madrasah Diniyah. Statistika Pendidikan-Direktorat Jenderal Pendidikan Islam, pp. 105-109. Jakarta, Indonesia.

Kremen, C., Niles, J.O., Dalton, M.G., Daily, G.C., Ehrlich, P.R., FAY, J.P. et al. (2000) Economic incentives for rain forest conservation across scales. Science, 288, 1828-1832.

LuBis, A.R. (2006) Islam and natural resources management. Batang Gadis National Park. Workshop report.

Mangunjaya, F.M. \& Aвbas, A.S. (2009) Khazanah Alam: Menggali Tradisi Islam untuk Konservasi Alam [Khazanah Nature: Exploring the Islamic tradition for the Conservation of Nature]. Yayasan Obor Indonesia, Jakarta, Indonesia.

Mangunjaya, F.M. \& McKay, J.E. (2012) Reviving an Islamic approach for environmental conservation in Indonesia. Worldviews, $16,286-305$.

McKay, J.E. (ed.) (2013) Integrating Religion within Conservation: Islamic Beliefs and Sumatran Forest Management. Durrell Institute of Conservation and Ecology, University of Kent, Canterbury, UK.

Measey, M. (2010) Indonesia: a vulnerable country in the face of climate change. Global Majority E-Journal, 1, 131-145.

Mikusiński, G., Possingham, H.P. \& Blicharska, M. (2013) Biodiversity priority areas and religions-a global analysis of spatial overlap. Oryx, 48. Http://dx.doi.org/10.1017/So030605312000993 [accessed September 2013].

Miller, T. (2009) Mapping the global muslim population: a report on the size and distribution of the world's muslim population. Pew Research Center. Http://pewforum.org/2009/10/07/mapping-theglobal-muslim-population/ [accessed 19 March 2013].

MUi (Majelis Ulama Indonesia) (2011) Fatwa MUI Tentang Pertambangan Ramah Lingkungan. Kementerian Lingkungan Hidup, Jakarta, Indonesia.

Schneider, H. (2013) The future face of conservation: could it be female? Oryx, 47, 1-2.

Sodhi, N.S., Davidar, P. \& RaO, M. (2010) Empowering women facilitates conservation. Biological Conservation, 143, 1035-1036.

The Jakarta Post (2011) Ministry employs 5,00o preachers to preserve forests. Http://www.thejakartapost.com/news/2011/07/17/ ministry-employs-5000-preachers-preserve-forests.html [accessed 10 October 2013].

WORLD BANK (2006) Faiths and the environment. World Bank report. Washington, DC, USA.

YonARIZA (1998) The continuity of matrilineal systems within a market economy. Philippine Journal of Third World Studies, 13, 37-50.

\section{Biographical sketches}

JEANne MCKay has research interests in the local beliefs and natural resource-use patterns of indigenous communities, conserving ecosystem services as a basis for forest protection, and incentive-based schemes for conserving rainforests. FACHRUDDIN MANGUNJAYA is interested in the role that religion plays in protecting the environment. 
His current work focuses on Islam and ecology and education for sustainable development in Indonesia. YOAN Din a t a has extensive experience working with local communities in West Sumatra, particularly on tiger conservation issues. ST UART HARROP's research interests include the international regulation of traditional practices as they support conservation, agriculture and the environment in international law and policy. FAZLUN KHALID is the founding Director of the Islamic Foundation for Ecology and Environmental Sciences and is an eco-theologian, with faith-based projects in Zanzibar, Nigeria, Tanzania and Indonesia. 